\title{
A GUARDA COMPARTILHADA: UMA EVOLUÇÃO SOCIAL
}

\author{
Valéria Nahas Fagundes ${ }^{1}$
}

\section{INTRODUÇÃO}

A guarda compartilhada foi introduzida na legislação brasileira pela Lei n. 11.698/08, que alterou os artigos 1.583 e 1.584 do Código Civil Brasileiro e, em face da importância e atualidade do tema, mereceu neste artigo algumas considerações.

O $\S 1^{\circ}$ do artigo 1.583 define: "compreende-se por guarda compartilhada a responsabilização conjunta e o exercício de direitos e deveres do pai e da mãe que não vivam sob o mesmo teto, concernentes ao poder familiar dos filhos comuns".

A guarda compartilhada possui semelhanças com a guarda conjunta e indistinta exercida pelos pais na constância da união conjugal.
Na guarda compartilhada, na hipótese de não se estabelecer uma guarda dos filhos em períodos exatamente iguais, em face das dificuldades de ordem prática que isso evidentemente acarretaria, o genitor que não exerce a guarda do filho por maior período de tempo, não obstante, participa efetivamente do desenvolvimento do menor. A partir da Lei n. 11.698/08, essa modalidade de guarda foi escolhida pelo legislador brasileiro como aquela que preferencialmente deve ser adotada nas hipóteses de separação de casais com filhos menores. Também existe a possibilidade de ser aplicada em relação a terceiros que tenham estabelecido vínculo afetivo tal com o menor que a não fixação de guarda conjunta traria prejuízos ao desenvolvimen-

1 Bacharel em Ciências Jurídicas e Sociais pela Pontifícia Universidade Católica do Rio Grande do Sul - PUCRS - 2000. Licenciada em Letras, Formação em Língua e Literatura Francesa pela Pontifícia Universidade Católica do Rio Grande do Sul - PUCRS - 1986. Aluna ouvinte da Turma de Mestrado em Direito de Família na Universidade Federal do Rio Grande do Sul. Funcionária concursada, Assessora da Terceira Vice-Presidência do Tribunal de Justiça do Rio Grande do Sul. 
to da criança ou do adolescente. Em caso de inexistência de acordo entre os guardiães, a guarda compartilhada deve ser fixada sempre que possível, devendo ser privilegiado o que for melhor para a criança.

No presente artigo, faz-se uma breve consideração a respeito do poder familiar e sua evolução, até chegar ao momento atual. Relacionaremos princípios orientadores da guarda que culminaram na ênfase ao princípio do melhor interesse da criança. Apresentaremos os tipos de guarda, com suas características. A guarda compartilhada será detalhada em capítulo à parte, merecendo destaque a alienação parental como forma de perda da guarda.

\section{CONCEITO}

A guarda é um dos atributos do poder familiar. É o instituto jurídico através do qual se atribui ao guardião (ou aos guardiães) um complexo de direitos e deveres a serem exercidos com o objetivo de proteger e prover as necessidades de desenvolvimento do menor não emancipado. $\mathrm{Na}$ constância da união conjugal, a guarda é, por essência, exercida por ambos os pais em igualdade de responsabilidades, indistintamente. As decisões importantes, que afetam a vida do filho, bem como as tarefas diárias que importem na educação do menor, estão igualmente a cargo de cada um dos genitores. Assim, qualquer dos pais, em conjunto preferencialmente, em separado se necessário, toma diariamente decisões a respeito de saúde, educação, garantias econômicas, divisão e direitos e deveres para organização do lar (Robles, 2009).

Em caso de ruptura de união conjugal em que os pais dividiam a guarda dos filhos na dinâmica do seu lar, contudo, deve ser estabelecido pelos pais ou pelo juiz quem exercerá o múnus de proteger e ajudar a desenvolver os menores frutos dessa relação. Da mesma forma, deve ser estabelecida a guarda em hipóteses em que os pais titulares preferenciais do poder-dever de guarda, por qualquer motivo não o exerçam.

Mesmo com a prevalência do melhor interesse do menor, não se pode imaginar que a guarda compartilhada tenha trazido - ou venha a trazer - a solução definitiva para os problemas de direito de família em relação ao desagrupamento familiar. O ser humano é essencialmente complexo e, na separação de um casal, sempre há sofrimento para a família até então constituída.

A guarda deve ser fixada a quem tenha condições de exercê-la em benefício do menor, com o objetivo de proteger e prover as necessidades de desenvolvimento desse ser em formação. A Lei n. 11.698/02 indica a preferência pela fixação da guarda de 
forma compartilhada entre os pais, mas pode também ser fixada de forma unitária, ou alternada, como veremos mais tarde. Da mesma forma, em benefício do menor, pode ser determinada a guarda, nas mesmas modalidades referidas acima, aos avós, tios, irmãos mais velhos etc., sempre tendo em vista o que for melhor para o menor.

O princípio básico para o estabelecimento da guarda é a possibilidade, ainda que abstrata, de que o guardião apresente condições de exercer esse múnus no melhor interesse do menor.

Também merece destaque que, em vista dos princípios do superior interesse da criança e da proteção integral da família, cada vez mais comuns são ações judiciais em que outros familiares ou terceiros em que se tenha desenvolvido uma relação de afeto buscam o reconhecimento do direito de visita, para a manutenção da convivência com o menor. Com grande sintonia, a maior parte das decisões judiciais tem entendido que o direito de visitação não é exclusivo do pai não detentor da guarda, reconhecendo a avós, irmãos etc. o mesmo direito, sempre que isso se der em benefício do menor.

\section{UM BREVÍSSIMO PANORAMA HISTÓRICO LEGISLATIVO}

O compartilhamento da guarda dos filhos é um dos resultados de uma série de evoluções sociais. No mundo ocidental, notadamente de duas grandes alterações de paradigmas: o princípio da igualdade entre homens e mulheres e o reconhecimento da condição plena de sujeitos de direito a crianças e adolescentes.

No mundo antigo, o afeto natural, embora eventualmente pudesse se fazer presente entre os membros de uma organização familiar, não definia o elo que envolvia essa família. Mulheres e filhos submetiam-se completamente ao poder do chefe do grupo. Esse tipo de agrupamento familiar foi disciplinado tanto no Código de Manu, como no Código de Hamurabi, como na Grécia antiga ou na civilização romana. Em Cidade Antiga, obra-prima de Fustel de Coulages, o autor afirma:

O antigo direito não é obra do legislador, o direito, pelo contrário, impôs-se ao legislador. Teve sua origem na família nasceu ali espontânea e inteiramente elaborado nos antigos princípios que a constituíram. Originou-se das crenças religiosas universalmente admitidas na idade primitiva destes povos que exerciam domínio sobre as inteligências e sobre as vontades (Coulanges, 2006).

Despontando entre os seus contemporâneos do ponto de vista jurídico, o berço da civilização é indiscutivelmente a civilização romana, com sua forte regulamentação e presença clara de distribuição de direitos e deveres. 
Na sociedade romana, que se organizou a partir da necessidade de as pessoas se organizarem em grupos ou clãs, o poder se centrava na figura do pater, que determinava a religião familiar e se incumbia da proteção do grupo todo.

Em que pese a indiscutível autoridade paterna, há quem defenda que, nessa época, a maior autoridade não era o pai, mas, sim, a religião doméstica. Ao pai cabia o dever da implementação do culto doméstico, de honra aos antepassados e adoração aos deuses da família (Levy, 2008, p. 6).

$\mathrm{O}$ primeiro parentesco a surgir na sociedade romana foi da agnação, decorrente da submissão de um grupo ao paterfamilias, como referido no texto Institutas, de Gaio, jurisconsulto romano do século II, que estabelece que são chamados agnatos aqueles cuja relação decorre do direito, explicitando que essa relação surge do sexo masculino. ${ }^{2}$ Transmitia-se somente pela linha paterna e não levava em consideração a consanguinidade. Representava um núcleo social em que o parentesco era puramente derivado da submissão ao chefe da família. O conceito era puramente jurídico e social.

Mais tarde, o direito passou a considerar o parentesco biológico ou consanguíneo, definido pela cognatio. Esse parentesco representa aquele existente entre os pais e os filhos e todos os que têm ascendentes comuns e era entendido incluindo os liames pela linha materna. ${ }^{3}$

O poder pátrio admitia um domínio quase ilimitado do pater familias. Mulheres não eram sujeito de direito ${ }^{4}$, e o pater, senhor do Lar, possuía um poder absoluto em relação aos filhos e demais integrantes do núcleo familiar. Alves (2008, p. 629) chama atenção que se incluía dentre os direitos do pater o de matar, vender ou expor seu filho. O pater familias possuía o Jus Vitae et Necis (Direito de Vida e Morte); o Jus Exponendi (Direito de abandonar o filho menor, nascido aleijado ou monstruoso); o Jus Vendendi (Direito de vender os dependentes como escravos a outro pater

2 No original: Gaius. Institutiones. 3.10 - Vocantur autem adgnati, qui legitima cognatione iuncti sunt. Legitima autem cognatio est ea, quae per virilis sexus personas coniungitur).

3 No original: Gaius. Institutiones. 1.156 - At hi, qui per feminini sexus personas cognatione coniunguntur, non sunt adgnati, sed alias natarali iure cognate.

4 "Na época da República, a mulher não era sujeito de direito; a sua condição pessoal, a sua relação com os pais ou com o marido eram, não da competência do direito da cidade, mas do da domus, cujo chefe omnipotente era o paterfamilias" (Gilissen, 2003, p. 600). 
familias), além dos direitos de dar em adoção, emancipar, fazer casar ou de fazer divorciar os dependentes. O poder paterno somente se extinguia com a morte do pater famílias; com a capitis deminutio do pater; com a perda de sua liberdade ou cidadania; em certos casos de indignidade cometida pelo pater famílias e taxativamente estabelecidos no direito objetivo; com o acesso dos filii familias a certas dignidades e com a emancipação dos filii famílias.

Veja-se que, a família, nesse momento da história, era uma unidade política, jurídica, econômica e religiosa que se erigia em torno da figura masculina (Caio Mario, p. 18-19). A mulher, por muitos séculos, foi colocada em uma posição servil em relação ao homem, não lhe cabendo outro destino ou posição social.

Assim se manteve a posição feminina na organização familiar nos quatro períodos da Civilização Romana (Período Régio, República, Período do Principado e Monarquia Absoluta). Alves (2008, p. 630) destaca, contudo, o fato de que no período da monarquia houve leve alteração no direito dos filhos, passando o pátrio poder a ter um viés educativo e levemente corretivo.

A posição de inferioridade da mulher e dos filhos na hierarquia familiar não se alterou com o advento do Cristianismo. A religião influenciou o direito na relação entre pais e filhos e marido e mulher até os tempos modernos e, no decorrer da Idade Média, tomou maior vulto pela enorme influência da Igreja Católica que, na época, interpretava como necessária a submissão da mulher e dos filhos ao "chefe da família”. Ainda coadjuvante no seio da família, a mulher passou a ter o seu papel social e familiar definido como a imagem da personagem bíblica de Eva: alguém que foi retirada da Costela de Adão para satisfazê-lo. A mulher do início da Era Cristã ainda devia obediência ao marido e conduzia o lar segundo as determinações do "cabeça da família” (expressão bíblica).

Contudo, é preciso referir que foi nessa época que se passou a reconhecer vínculos de afeição e complementação entre homens e mulheres de uma forma que não se verificava nos tempos de Roma.

Da mesma forma, para Levy (2008, p. 9), há uma leve diminuição da intensidade do poder familiar no período feudal: os filhos passam a ter direito à vida (a Igreja passa a punir o aborto e a exposição dos filhos).

A chefia familiar masculina esteve presente em quase todas as civilizações em toda história, sem significativas alterações no chamado Pátrio Poder, até a época da Revolução Francesa e das Teorias Jusnaturalistas. Como resultado emblemático das conquistas da Revolução Francesa, o Código Civil Francês, também cha- 
mado de Código de Napoleão, introduziu a noção de temporariedade do cargo do poder familiar, a possibilidade de exercício do encargo pela mãe na falta do pai e o direito de o filho possuir bens (Rizzardo, 2006). Ainda, Levy (2008, p. 9) destaca que a supressão do termo "bastardo" da linguagem jurídica e propostas de eliminação de distinção entre os filhos se fizeram marcantes no período.

Contudo, mesmo o Código de Napoleão - indubitavelmente inovador - coloca a mulher sob a tutela do marido. O artigo 213 do Código Civil Francês original dispunha: "Le mari doit protection à sa femme, la femme obéissance à son mari” (“O marido deve proteção a sua mulher, a mulher obediência a seu marido”). Napoleão chegou a declarar diante do Conselho de Estado: “A Natureza fez de nossas mulheres nossas escravas. O marido tem o direito de dizer à mulher: 'Senhora, não saireis de casa, não ireis ao teatro, não vereis tal pessoa! Isto é, senhora, vós me pertenceis de corpo e alma,". ${ }^{5}$

Vê-se que, mesmo decorrendo da Revolução Francesa, que foi um marco da busca pela igualdade, o Código Civil de Napoleão reprisou o poder patriarcal, reforçando a noção de chefe de família cujo poder se estende aos filhos e à esposa, deixando ao Século XX (e ao Século XXI na sequência da evolução sociológico-filosófico-jurídica) o protagonismo das grandes transformações ocorridas na área familiar.

Duas grandes guerras e profundas alterações econômicas desencadearam a redefinição dos papéis familiares: as mulheres se lançaram ao mercado de trabalho, passando a buscar o reconhecimento da igualdade sexual, os homens se tornaram mais participativos na relação familiar e menos autoritários e os filhos menores passaram a ocupar lugar de destaque no seio familiar, por se tratar de seres em processo especial de desenvolvimento. A sociedade e o Estado foram se transformando no reconhecimento dessa família evoluída.

\section{O PODER FAMILIAR NO BRASIL}

Por quase um século, a partir da Proclamação da Independência, o Brasil foi regido pela Legislação Portuguesa: as Ordenações.

\footnotetext{
5 No original: "La nature a fait de nos femmes nos esclaves. Le mari a le droit de dire à sa femme : 'Madame, vous ne sortirez pas ! Madame, vous n'irez pas à la Comédie ! Madame, vous ne verrez pas telle ou telle personne ! c'est-à-dire : Madame, vous m’appartenez corps et âme ! "’ Disponível em: http://www.communisme-bolchevisme. net/download/La_femme_et_le_communisme.pdf Acesso em: 02 ago. 2013.
} 
Assinala Levy (2008, p.10) que o Pátrio Poder na época das Ordenações cessava com o decurso do tempo e a noção temporal da submissão dos filhos ao poder familiar só se deu com a fixação, em 1931, da maioridade legal aos 21 anos, com aquisição da capacidade civil plena.

O primeiro grande mérito que se pode destacar com a edição do Código Civil de 1916 é que, como referido, pela primeira vez em quase cem anos de independência, o Brasil ganhou uma legislação Civil própria.

Fortemente influenciado pela Codificação de Napoleão, como se sabe, no âmbito do direito de família, o Código Civil Brasileiro de 1916 centralizou a autoridade familiar no marido. O legislador atribuiu ao marido, como chefe da família, o exercício do pátrio poder e, somente na sua falta ou impedimento, à mulher (Brasil, Código Civil de 1916, artigo 380).

Esse Código estratificou as relações familiares entre legítimas e ilegítimas, conferindo direitos somente às consideradas legítimas, inclusive excluindo a adoção da sucessão hereditária. Admitiu somente o casamento civil como sendo formador de família.

Em caso de separação, o Código Civil de 1916 atrelava o instituto da guarda à culpa pela dissolução do matrimônio. Não havia, portanto, uma prevalência no maior interesse da criança (Lotufo, 2007, p. 95).

Nessa linha, a codificação civil a respeito das relações familiares se manteve sem grandes modificações por mais de trinta anos.

Um salto legislativo ocorreu, entretanto, em 1949, quando entrou em vigor a Lei n. 883, que trata do reconhecimento dos filhos ilegítimos, permitindo seu reconhecimento através de ação própria.

Esses filhos, ainda discriminados pela sua ilegitimidade por não serem fruto de relacionamento marital, passaram a ter reconhecido, inclusive, direito a alimentos provisionais.

Outra grande evolução na legislação civil familiar pátria se deu com a edição do chamado Estatuto da $\mathrm{Mu}-$ lher Casada (Brasil, Lei n. 4.121/62), que revogou vários dispositivos do Código Civil e, dentre outros direitos, conferiu à mulher o direito de exercer o poder familiar, mesmo constituindo novo casamento. Reconheceu, também, à mulher o direito de dividir com o marido o exercício do poder familiar, podendo exercê-lo completamente na ausência deste.

Não houve, contudo, reconhecimento de igualdade entre os cônjuges, como se verifica do parágrafo único do artigo 380 do Código Civil de 1916 (Redação esta determinada pela Lei n. 4.121 de 1962) que dispôs: "divergindo os genitores quanto ao exercício do pátrio poder, prevalecerá a decisão do pai, ressalvado à mãe o direito de recorrer ao juiz para a solução da divergência”. A Lei n. 4.121/62, portanto, entendeu prevalecente a vontade do homem. 
Sobre a relevância dessa Lei:

O marco da emancipação jurídica da mulher, trazendo importantes mudanças, dentre as quais, no que se refere ao presente estudo, a modificação do artigo 380 do Código Civil de 1916, no sentido de conferir o pátrio poder aos pais, embora atribuísse seu exercício ao pai, relegando a mulher à condição de sua colaboradora, sendo que no caso de divergência entre os cônjuges quando ao exercício do pátrio poder, a prevalência da decisão era do pai, restando à mãe o direito de recorrer ao juiz para dirimir o conflito (Levy, 2008, p. 10).

Mesmo com a prevalência da posição paterna, essa lei representa uma das maiores conquistas das mulheres no âmbito do direito, havendo mudança da sua posição na instituição familiar. Destaca-se, ainda, que a Lei da Mulher Casada alterou o artigo 393 do Código Civil de 16, dispondo que novas núpcias contraídas pela mulher não acarretariam a perda do pátrio poder em relação aos filhos de casamento anterior.

Na esteira da legislação civil da maior parte dos países ocidentais, com grande expectativa social e muitas discussões jurídicas, quinze anos mais tarde, no ano de 1977, entrou em vigor a Lei n. 6.515, a Lei do Divórcio, que passou a regular os casos de dissolução da sociedade conjugal e do casamento, explicitando seus efeitos. Além disso, autorizou a opção, pela mulher, de utilizar o patronímico do marido e elevou o Regime Parcial de Bens ao status de regime legal. Dispôs sobre o encerramento dos vínculos familiares, admitiu o reconhecimento de filhos ilegítimos mesmo na vigência do casamento. Representou grande avanço na conquista dos direitos dos filhos, vez que lhes conferiu o direito de serem reconhecidos, independente do estado civil dos genitores e, ao mesmo tempo, conferiu-lhes direitos sobre o patrimônio do pai.

A Lei do Divórcio, contudo, manteve a culpa como motivo para o deferimento da guarda dos filhos menores a ser atribuída ao cônjuge não culpado pela separação.

Em 1979, foi aprovada a Lei n. 6.697, chamada de Código de Menores. Criou a adoção plena, que reconheceu direitos sucessórios e integração familiar ao filho adotado, e a adoção simples, que deferia ao adotado metade dos bens que coubesse ao filho legítimo. O Código de Menores foi criado com o objetivo primordial de regularizar a situação dos meninos e das meninas encontrados nas ruas dos grandes centros urbanos. Esse Código recebeu duras críticas por ser altamente discriminatório e porque sua aprovação se deveu a questões de segurança pública, e não à proteção integral às crianças que se encontravam em situação de risco. Seus dispositivos previam punição a "menores delinquentes”, pois se acreditava que 
estes não poderiam se adaptar à vida em sociedade, devendo ser afastados.

AConstituição Federal de 1988 foi um marco de transformação, inovando todo o nosso ordenamento jurídico. Trouxe isonomia em relação a direitos de homens e mulheres, alterando, inclusive, para maior adequação, a designação do instituto do pátrio poder, que passou a se chamar de poder familiar. Reconheceu a isonomia entre os cônjuges, proibiu a distinção entre os filhos e equiparou modalidades de uniões conjugais, dando fim a mais de dois mil anos de discriminação entre homens e mulheres.

Antes da Constituição Federal de 1988, os filhos classificavam-se em: biológicos, legítimos, ilegítimos, naturais, espúrios, adulterinos, incestuosos e adotivos. Conceitos totalmente retrógrados e preconceituosos, que levaram muitas décadas para serem abandonados pelo legislador.

A Lei n. 8.069/90, que veio a revogar o Código de Menores, trouxe substanciais inovações no tratamento jurídico da criança e do adolescente, merecendo destaque o reconhecimento do menor enquanto sujeito de direitos a serem amplamente tutelados. Notável mudança em que o menor deixou de ter um lugar passivo e passou a ser personagem principal nas decisões e matérias que o envolvesse. Hoje é claro o entendimento de que, sempre que seja possível, deve ser ouvido o menor nos assuntos que possam vir a afetá-los.
Merecem destaque "o direito acuidados e assistência especiais", disposto na Declaração Universal de Direitos Humanos das Nações Unidas, de 1948, e na Declaração Universal dos Direitos da Criança, de 1959:

a criança gozará de proteção especial e disporá de oportunidade e serviços, a serem estabelecidos em lei por outros meios de modo que possa desenvolver-se fisicamente, moral, espiritual e socialmente de forma saudável e normal, assim como em condições de liberdade e dignidade. Ao promulgar leis com este fim, a consideração fundamental a que se atenderá será o interesse superior da criança.

Essas garantias têm sido adotadas nas legislações de diversos países. No Brasil, especialmente no Estatuto da Criança e do Adolescente:

Art. $3^{\circ} \mathrm{A}$ criança e o adolescente gozam de todos os direitos fundamentais inerentes à pessoa humana, sem prejuízo da proteção integral de que trata esta Lei, assegurando-se lhes, por lei ou por outros meios, todas as oportunidades e facilidades, a fim de lhes facultar o desenvolvimen-to físico, mental, moral, espiritual e social, em condições de liberdade e de dignidade. Art. $7^{\circ} \mathrm{A}$ criança e o adolescente têm direito à proteção à vida e à saúde, mediante a efetivação de políticas sociais públicas que permitam o nascimento e o desenvolvimento sadio e harmonioso, em condições dignas de existência. Art. 15. A cri- 
ança e o adolescente têm direito à liberdade, ao respeito e à dignidade como pessoas humanas em processo de desenvolvimento e como sujeitos de direitos civis, humanos e sociais garantidos na Constituição e nas leis (Brasil, ECA, Artigos $3^{\circ}, 7^{\circ}$ e $15^{\circ}$ ).

O Código Civil de 2002, seguindo a linha da Constituição Cidadã, aplicou os princípios da igualdade entre homens e mulheres, entre as diversas configurações familiares e entre os filhos, em atenção ao melhor interesse do menor.

As leis da guarda compartilhada (Lei n. 11.698/08) e da alienação parental (Lei n. 12.318/2010) completam as referências necessárias à ilustração da evolução do direito no que pertine às disposições legislativas centrais de proteção ao menor.

\section{DA GUARDA DOS FILHOS}

O instituto do Pátrio Poder, que vigeu desde as Ordenações Filipinas (no ano de 1603) até a Constituição Federal de 1988, privilegiava a figura do genitor varão em franca identificação com o pater famílias.

Da colonização portuguesa até o momento em que a mulher deixou de ser considerada relativamente incapaz (Lei n. 4.121/62 - Estatuto da Mulher Casada), passaram-se 462 anos. Mais 26 anos foram necessários para a constitucionalização da igualdade de direitos entre homens e mulheres na família (Constituição Federal de 1988), colocando fim ao antigo pátrio poder e ao poder marital.

De tudo o que foi dito aqui, vê-se que o caminho constitucional da igualdade entre homens e mulheres e de reconhecimento de crianças e adolescentes como pessoas em fase especial de desenvolvimento foi lento e árduo. Dos remotos tempos românicos do poder do pater familias, passando pela recente figura do chefe de família, aos dias atuais, o conceito de Pátrio Poder mudou suas características, acompanhando a evolução da sociedade, vindo a ser consagrado 1.630 do Código Civil vigente: “Os filhos estão sujeitos ao poder familiar, enquanto menores".

Sobre o tema, Akel (2009) afirma: "A igualdade constitucional de direitos e obrigações entre marido e mulher bem como do companheiro e da companheira não mais justificam a predominância feminina da guarda quando da ruptura da relação".

Assim, o Poder Familiar (ou a autoridade parental), como prefere Tepedino, autoriza os pais a "interferir na esfera jurídica dos filhos não no interesse dos pais, titulares do poder jurídico da educação, mas no interesse dos filhos, as pessoas em cuja esfera jurídica é dado ingerir".

Percebe-se, portanto, que a autoridade parental é natural, quanto às origens, e positiva, quanto à cogência, 
encerrando direitos e deveres a serem exercidos por ambos os pais, independentemente de serem ou não casados, em situação de equilíbrio.

A guarda dos filhos, ao lado da tutela e da adoção, compõe o Poder Familiar no conceito da autoridade dos pais. Durante a constância do relacionamento, exercem-na em conjunto, não havendo, salvo situações extremas, interferência externa nesse exercício.

A questão se torna mais juridicamente relevante quando da separação do casal.

Como já referido, antigamente a definição da guarda dos filhos era conferida com base na atribuição da culpa pela dissolução conjugal. Se fosse reconhecida a culpa de ambos os cônjuges pela separação, prioritariamente a guarda era dada à mãe, notadamente se se tratasse de guarda de crianças.

Havia uma presunção jurídica de que os filhos ficariam melhor atendidos sob a guarda da mãe e somente seria dada a guarda ao pai ou a outro ente familiar se a mãe demonstrasse que não teria condições de exercê-la. Ao lado de questões de saúde ou financeiras, havia disfarçada ou explicitamente uma avaliação moral dessa mãe. Ao lado dessa presunção jurídica também havia algumas presunções sociais que levavam à fixação da guarda material do menor à mãe: os homens não possuem uma vocação inata para cuidar de crianças, as mulheres a possuem; os homens foram educados somente para trabalhar fora de casa; os homens não conseguiriam trabalhar e cuidar dos filhos; homens não conseguem viver sozinhos e não conseguiriam contrair novas núpcias se tivessem que ficar com as crianças, e as crianças ficam melhores com as mães. Essas presunções sociais e culturais se alteraram de tempos em tempos, ou de região para região, mas regeram muitas das fixações extrajudiciais de guarda de menores, às vezes, interferindo, inclusive, na fixação judicial da guarda.

A regra apriorística era sexualmente discriminatória e, muitas vezes, a guarda estabelecida em detrimento dos interesses do menor. Em inúmeras situações, a "regra" de se conceder a guarda à mãe se mostrou insuficiente ou inadequada para equalizar os anseios dos pais e dos filhos menores.

Hoje tem-se que homens e mulheres querem o direito de cuidar e educar os filhos, assim como dividir as responsabilidades que vêm da relação parental. Não se tem mais, como absoluta, a existência de uma capacidade feminina inata de cuidar dos filhos, não se acredita em uma incapacidade funcional masculina de fazê-lo, não se espera que somente o pai seja responsável pela manutenção do menor, não se atribui somente ao varão as condições morais e de valores sociais que devem ser passados aos filhos, 
não se imagina que só a mãe tenha a afetividade necessária à formação do menor. Ao contrário, são reconhecidos a ambos os genitores os direitos e deveres inerentes da condição parental. A igualdade abstrata é apriorística e, no caso concreto, é funcionalmente complementar.

Os novos paradigmas inseridos na Constituição Federal de 1988, com proteção dos direitos humanos com base na igualdade e na proteção do estado democrático de direito, conferiram tratamento legislativo diferenciado à criança e ao adolescente.

O Código de Menores que, como referido, centrava-se na repressão e na segurança social, deu lugar à doutrina pela proteção integral, deslocando a criança no sistema legal brasileiro a uma condição privilegiada, em decorrência de sua condição natural de vulnerabilidade. As crianças e os adolescentes passaram a ser reconhecidos como pessoas em fase especial de desenvolvimento e, nessa condição, mereceram especial proteção.

\section{PRINCÍPIOS \\ CONSTITUCIONAIS RELACIONADOS À GUARDA}

A nossa atual Constituição da República, também chamada de "Constituição Cidadã”, adotou como princípio basilar o Princípio da Dignidade da Pessoa Humana. Esse princípio, projetado em todo texto constitucional, no campo do direito de família originou outros princípios, igualmente protegidos. Mesmo que nem todos estejam expressos no texto constitucional, emergem da simples leitura da Carta Maior. Destacam-se o Princípio da Igualdade Conjugal, o Princípio do Superior Interesse da Criança, o Princípio da Proteção da Família; o Princípio da Paternidade Responsável; o Princípio da Proteção Integral da Criança e do Adolescente e o Princípio da Afetividade e da Solidariedade Familiar, dentre outros. São princípios autoexplicativos, razão pela qual deixa-se de tecer maiores considerações sobre cada um deles.

\section{O PRINCÍPIO DO SUPERIOR INTERESSE DA CRIANÇA}

A guarda de menores deverá ser fixada judicialmente em duas situações básicas: em casos de dissolução da união conjugal (tratada no âmbito do Código Civil) e nas hipóteses em que crianças e adolescentes se encontrem em situação de risco (no âmbito do Estatuto da Criança e do Adolescente). Em ambos os casos, a guarda deve ser fixada no melhor interesse do menor.

O Princípio do Melhor Interesse da Criança e do Adolescente está previsto na Constituição Federal de 1988, em seu artigo 227, caput, e no 
Estatuto da Criança e do Adolescente em seus artigos $4^{\circ}$, caput, e $5^{\circ}$.

Esse princípio condensa a maior evolução de todos os tempos quanto aos direitos do menor e tem sido aplicado massivamente em todos os Tribunais do país.

O menor, agora sujeito integral de direitos, passou a ser alvo de todo o cuidado dispensado pela família, pela sociedade e pelo Estado.

Esse melhor interesse, por se tratar de conceito axiológico, depende sempre da análise do caso concreto.

Assim, nos dias de hoje, os operadores do direito, ao tratar da guarda, devem levar em consideração o que venha a favorecer a realização pessoal do menor, independentemente da relação biológica que tenha com seus pais.

\section{DA CLASSIFICAÇÃO QUANTO À TITULARIDADE DA GUARDA}

Os genitores são os titulares naturais no exercício da guarda dos filhos (Levy, 2008, p. 50).

Nas hipóteses em que esses não apresentem condições de exercitar esse múnus, o exercício da guarda poderá ser conferido a terceiros, sempre em atenção ao melhor interesse dos menores. A possibilidade do exercício da guarda por terceiros está prevista no artigo 1.594, § $5^{\circ}$ do Código Civil, com as modificações incluídas pela
Lei n. 11.698/08, que incluiu relações de afetividade e afinidade aos critérios previstos para o deferimento de guarda a terceiros:

Art. 1.584. A guarda, unilateral ou compartilhada, poderá ser:

II - decretada pelo juiz, em atenção a necessidades específicas do filho, ou em razão da distribuição de tempo necessário ao convívio deste com o pai e com a mãe. (Incluído pela Lei $\mathrm{n}^{\circ} 11.698$, de 2008).

$\S 5^{\circ} \mathrm{Se}$ o juiz verificar que o filho não deve permanecer sob a guarda do pai ou da mãe, deferirá a guarda à pessoa que revele compatibilidade com a natureza da medida, considerados, de preferência, o grau de parentesco e as relações de afinidade e afetividade (Incluído pela Lei n. 11.698, de 2008).

Assim, o legislador pátrio valorou enquanto requisitos jurídicos o grau de parentesco, a afinidade e a afetividade para o deferimento da guarda nos diversos modelos de exercício do instituto, acompanhando as evoluções sociais que privilegiam a afetividade e o bem-estar nas relações familiares.

Vê-se, assim, que o instituto da guarda não é exclusivo dos pais ou outros quaisquer que tenham a titularidade e o exercício do poder familiar, podendo ser conferida a terceiros em diversas situações se assim o exigir o melhor interesse da criança ou do adolescente ou se os genitores não puderam exercê-la, seja por motivos fáticos, seja por decisão judicial. 
Tem se tornado frequente nos nossos tribunais o pedido de guarda por tios ou avós, tendo em vista a impossibilidade de os pais exercerem a guarda no melhor atendimento dos interesses do menor. Muitas vezes, o progenitor já detém a guarda fática e o deferimento da guarda visa regularizar uma situação já existente. O Superior Tribunal de Justiça, em casos como esse, costuma deferir, de forma não definitiva, a guarda aos avós interessados, visando dar continuidade ao afeto e à proteção da família. São processos em que muitas vezes não há conflito, pois pais e avós concordam com a alteração da guarda que, no mais das vezes, se deve a uma impossibilidade financeira. "Não será o Poder Judiciário que deixará a marca da beligerância nessa relação pacífica", manifestou-se a Ministra Nancy Andrighi no EResp 993458/ MA em pronunciamento representativo da visão do Superior Tribunal de Justiça sobre o tema.

\section{DA CLASSIFICAÇÃO QUANTO À FORMA DO EXERCÍCIO DA GUARDA}

A guarda exercida durante a constância da relação conjugal é comum ou conjunta, como já referido. Ambos os genitores têm parcela igual do poder familiar sobre os filhos em igualdade de responsabilidades. Arranjos particulares entre o casal decidem os fatos importantes da vida do menor e são igualmente responsáveis pelos reflexos das suas escolhas.

Em casos de separação do casal, diferentemente, outras modalidades de guarda são utilizadas, dependendo do comportamento, do caráter e do temperamento de cada genitor.

A guarda, nessas hipóteses, pode ser unilateral (ou exclusiva), alternada, aninhamento (ou nidação), ou compartilhada, objeto central deste estudo. Importa referir, contudo, que nenhuma delas prevê a cisão ou diminuição dos atributos do poder familiar.

A guarda unilateral é a forma mais comum de guarda. É aquela em que um dos pais fica com o encargo físico do cuidado aos filhos e o outro exerce as visitas. Cabe ao genitor descontínuo, além do direito de visita, a fiscalização do exercício da guarda do pai-guardião. Além disso, deve decidir sobre a emancipação dos filhos e autorização para viagens.

A escolha do guardião pode-se dar por acordo entre os genitores ou por determinação judicial. A guarda unilateral deve ser deferida ao pai que tiver melhor condições de exercê-la, competindo ao não guardião o dever de supervisionar os cuidados recebidos pelo infante.

É pacífico o entendimento de que essa modalidade de guarda obtém ótimos resultados se as combinações não forem extremamente rígidas e houver boa vontade dos pais, em respeito mútuo. 
Tem sido criticado esse modelo nas hipóteses - infelizmente bem comuns - em que a participação efetiva do genitor que não recebeu a guarda se limita ao pagamento da pensão alimentar estabelecida, passando somente raros momentos com os filhos. Esse comportamento, que acaba por se traduzir em uma dinâmica desse relacionamento, provavelmente interferirá no desenvolvimento dos filhos, de forma negativa.

A guarda alternada - aquela em que há uma concentração do poder parental, por um certo período, para um dos genitores - não tem recebido boas críticas por parte de juízes, da doutrina ou de psicólogos. Esse tipo de guarda privilegia o interesse dos pais e, segundo os especialistas, prejudica a formação dos filhos pela supressão ou confusão de referências básicas de moradia, hábitos alimentares, regras quanto a horários etc., comprometendo sua estabilidade emocional e física. A guarda alternada ressente-se da constância dos objetos conhecidos, do mundo da criança, das regras, reclama-se a necessidade de se manter a constância, na medida do possível, do ambiente do menor.

A criança necessita de um porto seguro que a casa de origem proporciona, na qual possa se reconhecer no ambiente conhecido e estável. Preservar esse lugar significa manter constante o mundo da criança, já que o quarto da criança representa, inicialmente, a extensão do seu mundo in- terno, pois é através da constância dos objetos conhecidos e familiares repletos de significados em seu ambiente que a criança reencontrará a paz que precisa para lidar com a instabilidade que a situação acarreta.

Nesse sentido, a lição de Grisard Filho (2002, p. 190): “Não há constância de moradia, a formação dos hábitos deixa a desejar, porque eles não sabem que orientação seguir, se do meio familiar paterno ou materno".

Isso não impede que possa ter, é fundamental que tenha, um espaço na casa do genitor descontínuo, pois isso representa para a criança a comprovação concreta de ter um espaço no coração e na mente do mesmo. Como nos prestigia o dizer de Grisard Filho citado anteriormente.

A nidação, ou aninhamento, é aquela em que os menor fica fixado na residência enquanto os pais se alternam nessa residência. Não há previsão no nosso ordenamento, sendo referida apenas por questões acadêmicas.

A guarda compartilhada será abordada a seguir.

\section{A GUARDA COMPARTILHADA}

Duas décadas se passaram da promulgação da Constituição Federal e a edição da Lei n. 11.698/08 veio trazer ao tema da guarda de menores substancial evolução, com a alteração dos artigos 1.583 e 1.584 do Código Civil. 
A Lei n. 11.698/08 instituiu e disciplinou o instituto da guarda compartilhada em lugar da guarda unilateral, até então preferencialmente utilizada. Naturalmente, como costuma acontecer nos processos legislativos, a Lei n. 11.698/08 foi antecedida por doutrina e jurisprudência - além de legislações estrangeiras - que já defendiam a utilização da guarda compartilhada para compor conflitos familiares decorrentes da ruptura da vida em comum.

A guarda compartilhada é definida no artigo 1.583 , par $1^{\circ}$, do Código Civil: “é a responsabilização conjunta e o exercício de direitos e deveres do pai e da mãe que não vivam sob o mesmo teto, concernentes ao poder familiar dos filhos comuns".

Esse tipo de guarda funciona como um sistema em que os menores, filhos de pais separados, estão sujeitos à autoridade equivalente de ambos os genitores que, em conjunto, tomarão decisões importantes quanto à criação, educação e bem-estar da criança ou do adolescente. Essa espécie de guarda busca se aproximar daquela exercida pelos pais em conjunto quando ainda não havia sido dissolvida a relação conjugal.

Dizendo de outra forma, a Guarda Compartilhada surgiu da necessidade de se equalizar o melhor interesse do menor com a necessidade de ambos os pais de educarem seus filhos, participando ativamente das decisões relativas ao menor e de se manter como re- ferência identitária, afetiva e familiar para seus filhos. A vida em família é direito garantido constitucionalmente (Constituição Federal, art. 227) e diz respeito a diversos graus de parentesco, como irmãos, avós, tios, primos. Ou seja, a Constituição da República protege, pelo caráter de ser humano em desenvolvimento que possuem as crianças e os adolescentes, a convivência do menor com todos os membros familiares que possam lhe servir de referencial para desenvolvimento de sua identidade. Seja com a família natural, seja com a substituta, o menor tem o direito de conviver com ela, integrando-se. A ideia básica é manter o menor em ambiente de amor e proteção familiar semelhante ao que teria se não se tivessem separado os pais. Procura-se dar continuidade às relações da criança na família dissociada de forma bem próxima do que seria em uma família intacta. Contudo, as mudanças são inevitáveis, enquanto consequência lógica da ruptura da união conjugal.

O desagrupamento familiar altera a vida das crianças e dos adolescentes, e é comum que o ex-casal misture sentimentos e ressentimentos e deixe de priorizar o que é melhor para os filhos. Dessarte, ainda que, em tese, a guarda compartilhada seja o modelo ideal de guarda de menores filhos de pais separados - e por isso é o modelo preferencial no nosso sistema legal desde a edição da Lei n. 11.698/08, na prá- 
tica depende de alguns requisitos para ser aplicada e representar realmente o melhor interesse do menor.

O estabelecimento da guarda compartilhada como a mais adequada ao caso concreto deve, primeiramente, levar em consideração as condições psicológicas e a capacidade dos genitores. Notadamente, no que diz respeito aos níveis de confiança e capacidade de diálogo entre os pais.

Esse elemento anímico é essencial para que essa modalidade de guarda possa garantir uma nova dinâmica relacional entre os envolvidos. Os pais terão que transmitir aos filhos, para que a guarda compartilhada cumpra a sua função de proporcionar o melhor bem-estar aos menores, um estado tal de confiança que os filhos não sejam atingidos quanto aos seus referenciais de identidade e de proteção.

Os filhos não podem ser tratados como posse ou, pior, fonte de poder por qualquer das partes e não devem ficar no centro de rancores conjugais passados. Se os pais demonstrarem, durante o processo de guarda, que não têm capacidade de superar rancores em nome do superior interesse do menor, talvez um outro tipo de guarda, menos próxima, se revele a mais adequada àquela criança.

Dentre as maiores vantagens do instituto da guarda compartilhada estão o fim da regulamentação de visitas, o não afastamento do pai ou mãe que não detém a guarda e a não fragmentação identitária do menor, com a manutenção responsável e solidária dos direitos-deveres inerentes ao poder familiar, minimizando-se os efeitos da separação dos pais.

Assim, na medida do possível assim como faziam quando da convivência conjugal, ambos os pais devem participar da vida dos filhos, para que o menor se sinta "em casa" tanto na residência de um quanto na de outro. Inúmeros são os casos em que os filhos afirmam se sentir melhor sob a proteção da guarda compartilhada do que quando conviviam com ambos os pais sob o mesmo teto, por terem sido profundamente atingidos psicologicamente no período anterior à separação.

Como referimos antes, é o modelo ideal de guarda para pais separados em condições específicas. Contudo, em que pese o instituto da guarda compartilhada pretender aproximar a situação dessa nova conjugação familiar àquela de antes da separação, a guarda compartilhada nem sempre pode ser aplicada.

Em primeiro lugar, o $\S 2^{\circ}$ do inciso II do artigo 1.584 do Código Civil dispõe: “Quando não houver acordo entre a mãe e o pai quanto à guarda do filho, será aplicada, sempre que possível, a guarda compartilhada” (Incluído pela Lei n. 11.698, de 2008).

Parte dos juristas entende como um erro a imposição da guarda compartilhada na inexistência de acordo entre os pais. Afirmam que a hipó- 
tese representaria franco retrocesso porque o melhor interesse do menor não seria resguardado com a determinação judicial.

Diferentemente dessa parcela da doutrina, acreditamos que, ainda que a Lei n. 11.968/08 tenha claramente introduzido a guarda compartilhada como a guarda preferencial, também chamada de "guarda legal", deixou claro que será aplicada "sempre que possível”.

Entendemos não haver determinação legal de imposição, pelo juiz, da guarda compartilhada para qualquer caso. O legislador manifestou a preferência e condicionou a determinação às condições que apresentarem os pais de exercer o múnus em conjunto em benefício do menor.

Com a devida licença dos que entendem em sentido contrário, achamos evidente que não seria de se impor a guarda conjunta em situações em que não há o menor espaço para diálogo, em que haja conflitos potencialmente insolúveis ou haja graves indícios de violência por parte de um dos genitores, por exemplo. A guarda compartilhada, repete-se, é preferencial, sendo obrigatória somente se satisfeitas as condições paternas.

Nesse momento da reflexão, merece destaque o $\S 3^{\circ}$ do artigo 1.584 do Código Civil, também incluído pela Lei ${ }^{\circ} 11.698$, de 2008: Para estabelecer as atribuições do pai e da mãe e os períodos de convivência sob guarda compartilhada, o juiz, de ofício ou a requerimento do Ministério Público, poderá basear-se em orientação técnico-profissional ou de equipe interdisciplinar.

Ou seja, está prevista no texto legal a possibilidade de mediação interdisciplinar como etapa prévia da aplicação da guarda compartilhada quando não houver acordo dos pais sobre essa matéria. Assim, se não se revelar eficaz a mediação no sentido de equalizar a guarda compartilhada, excepcionalmente deverá ser aplicada a medida da guarda unilateral a quem se revelar em melhor condição de atender aos interesses do menor, nos termos do artigo 1.584, § 5 , do Código Civil.

\section{A GUARDA E A ALIENAÇÃO PARENTAL}

A alienação parental é um processo engendrado por um dos genitores, que consiste em programar uma criança ou adolescente para que despreze ou odeie o outro genitor, ou os parentes dele, sem que haja motivo para tanto. Estabelecido o processo de alienação, a criança (ou o adolescente) começa a contribuir para a campanha de desmoralização do genitor alienado. O fenômeno, desagregador do grupo familiar, produz efeitos ne- 
gativos muito sérios e muitas vezes incontornáveis nas relações entre pais e filhos. Por isso, despertou especial interesse nas áreas da psicologia e do direito, consagrando o novo campo epistemológico da Psicologia Jurídica, baseado na necessidade da multidisciplinaridade para melhor compreensão dos fenômenos emocionais que atingem todas as partes envolvidas num processo de separação, incluindo os filhos (Dias, p. 102).

A toda evidência, em termos de reconhecimento do fenômeno pelo Judiciário, tal identificação não substitui a necessidade de um diagnóstico por parte de profissionais qualificados, nos termos da Lei n. $12.318 / 10$.

A mais cruel das formas de alienação parental se dá com a implantação de falsas memórias de abuso sexual por parte do pai, fato - infelizmente - cada vez mais comum dentre as famílias alienadas.

Nesses casos, a mãe - não se tem notícia de implantação, por parte do pai, de falsa memória de abuso sexual - com raiva do pai do seu filho, busca interromper, por via judicial, os contatos da criança com seu genitor. Os sentimentos de destruição, ódio, inveja ou ciúme sobrepujam os cuidados que deveria ter para proteção do menor. As denúncias, nesses casos, devem ser analisadas com extremo cuidado, não podendo os ope- radores do direito se deixar envolver pela trama urdida pelo ódio do alienador, que busca manipular a justiça em detrimento do alienado, mesmo que à custa do desenvolvimento emocional dos filhos, as maiores vítimas (Dias, 2007, p. 110).

Tem-se que a falsa memória de abuso é, ela sim, gravíssimo e perverso abuso psicológico, pois as crianças são submetidas a uma mentira da qual não têm condições de se defender. Destrói a família toda, sendo que a certeza da verdade dificilmente volta a ser estabelecida. Ainda que possa ser identificada por profissionais qualificados, as sequelas que deixa nos menores pode ser tão grande como aquelas deixadas em crianças verdadeiramente abusadas. Ainda, o desmascaramento da farsa montada pela mãe também provoca sérias consequências, porque o filho, que ajudou a imputar ao pai uma conduta tão reprovável, costuma desenvolver grande sentimento de culpa pela deslealdade em relação ao pai e, ainda, se sente traído pela mãe, que foi capaz de usá-lo para uma sórdida vingança.

A caracterização de atos de alienação parental podem determinar a substituição da guarda ou inviabilizar a efetivação da guarda compartilhada.

Veja-se o texto legal quanto ao reconhecimento da prática de alienação por parte de um dos genitores: 
Art. 6o Caracterizados atos típicos de alienação parental ou qualquer conduta que dificulte a convivência de criança ou adolescente com genitor, em ação autônoma ou incidental, o juiz poderá, cumulativamente ou não, sem prejuízo da decorrente responsabilidade civil ou criminal e da ampla utilização de instrumentos processuais aptos a inibir ou atenuar seus efeitos, segundo a gravidade do caso:

I - declarar a ocorrência de alienação parental e advertir o alienador; II - ampliar o regime de convivência familiar em favor do genitor alienado;

III - estipular multa ao alienador;

IV - determinar acompanhamento psicológico e/ou biopsicossocial; V - determinar a alteração da guarda para guarda compartilhada ou sua inversão;

VI - determinar a fixação cautelar do domicílio da criança ou adolescente; VII - declarar a suspensão da autoridade parental.

Parágrafo único. Caracterizado mudança abusiva de endereço, inviabilização ou obstrução à convivência familiar, o juiz também poderá inverter a obrigação de levar para ou retirar a criança ou adolescente da residência do genitor, por ocasião das alternâncias dos períodos de convivência familiar.

Art. 70 A atribuição ou alteração da guarda dar-se-á por preferência ao genitor que viabiliza a efetiva convivência da criança ou adolescente com o outro genitor nas hipóteses em que seja inviável a guarda compartilhada (Brasil, Lei n. 12.318/10, artigos $6^{\circ}$ e $7^{\circ}$ ).
Nessa hipótese, a intervenção do Estado, por intermédio do Ministério Público e do juiz, pode ser decisiva para reorganizar a dinâmica segundo a lei e, portanto, de forma mais saudável.

\section{CONSIDERAÇÕES FINAIS}

Em síntese, o reconhecimento da possibilidade de guarda compartilhada no nosso ordenamento trouxe grande avanço histórico, jurídico e social e vem ao encontro da necessidade de ampliação de esforços para a efetivação princípio do melhor interesse do menor, haja vista os seus naturais benefícios em respeito ao papel de ambos os genitores na formação do menor.

$\mathrm{O}$ apontado risco de insucesso por eventual inexistência de acordo entre os pais do menor a respeito da guarda não se revela efetivo, sendo contornável pela prévia prática da mediação interdisciplinar, conforme permitido pelo recente art. 1.584 , § $3^{\circ}$, do Código Civil.

Ou seja, não havendo sucesso na mediação, hipótese estatisticamente pouco provável, é que se deve recorrer à excepcional guarda unilateral.

Importa ainda dizer que, não obstante seja possível se falar em guarda definitiva, o caráter definitivo da guarda se refere ao estabelecimento da guarda ao final do processo, em contraposição à guarda provisória, que será reanalisada no curso da lide. Fora do âmbito processual, a guarda nunca 
é definitiva, podendo ser modificada em qualquer tempo, sempre conforme o superior interesse do menor, como se verifica, por exemplo, em casos extremos de perda de guarda por terem-se configurado atos de alienação parental.

\section{REFERÊNCIAS}

AKEL, Ana Carolina Silveira. Guarda compartilhada - Um avanço para a família moderna. Disponível em www.ibdfam.org.br. Acesso em: 24 jul. 2013.

ALVES, José Carlos Moreira. Direito romano. Rio de Janeiro: Forense, 2008.

BARBOSA, Gabriella Ferrarese. DIAS, Maria Berenice (Org.). Incesto e alienação parental: realidades que a Justiça insiste em não ver.

BRASIL, Constituição Federal. Disponível em: http://www.planalto. gov.br/ccivil_03/Constituicao/ Constituicao.htm. Acesso em: 28 jul. 2013.

. Código Civil de 1916. Disponível em: http://www.planalto. gov.br/ccivil_03/Leis/1930-1949/ L0883.htm. Acesso em: 01 ago. 2013.

- Lei n. 833, de 21 de outubro de 1949. Dispõe sobre o reconhecimento dos filhos legítimos. Acesso: http://www. planalto.gov.br/ccivil_03/
Leis/1930-1949/L0883.htm. Acesso em: 28 jul. 2013. . Lei n. 4.121, 27 de agosto de 1962. Dispõe sobre a situação jurídica da mulher casada. Disponível em: http://www. planalto.gov.br/CCIVIL_03/ LEIS/1950-1969/L4121.htm. Acesso em: 28 jul. 2013. . Lei n. 6.515, de 26 de dezembro de 1977. Dispõe os casos de dissolução da sociedade conjugal e do casamento, seus efeitos e respectivos processos, e dá outras providências. Disponível em: http://www.planalto.gov.br/ ccivil_03/leis/16515.htm. Acesso em: 27 jul. 2013.

. Lei n. 6.697/79, de 10 de outubro de 1979. Institui o Código de Menores. Disponível em: http:/www.planalto.gov.br/ ccivil_03/leis/1970-1979/L6697. htm. Acesso em: 04 ago. 2013. . Lei n. 8.069, de 13 de julho de 1990. Dispõe sobre o Estatuto da Criança e do Adolescente e dá 
outras providências. Disponível em: http://www.planalto.gov. br/ccivil_03/Leis/L8069.htm. Acesso em 05/08/2013. Acesso em: 04 ago. 2013.

. Lei n. 11.698, de 13 de junho de 2008. Altera os arts. 1.583 e 1.584 da Lei n 10.406, de 10 de janeiro de 2002 - Código Civil, para instituir e disciplinar a guarda compartilhada. Disponível em: http://www.planalto.gov.br/ccivil_03/_Ato2007-2010/2008/Lei/ L11698.htm. Acesso em: 25 jul. 2013.

Lei n. 12.318 , de 26 de agosto de 2010. Dispõe sobre a alienação parental e altera o art. 236 da Lei n 8.069, de 13 de julho de 1990. Disponível em: http:// www.planalto.gov.br/ccivil_03/_ Ato2007-2010/2010/Lei/L12318. htm. Acesso em: 25 jul. 2013.

COULANGES, Numa-Denys Fustel de. A cidade antiga. Versão para E-Book E-BooksBrasil. São Paulo: Editora das Américas S/A., 2006.

GAIO, Institutiones. Sem data. Disponível em: http://www.vroma. org/ bcassidy/relation.html. Acesso em: 25 jul. 2013.

GILISSEN, John. Introdução histórica ao direito. 4. ed. Lisboa: Fundação Calouste Gulbenkian, 2003.

GRISARD FILHO, Waldir. Guarda compartilhada. Revista dos
Tribunais, 2. ed., 2002, p. 190).” Guarda compartilhada X guarda alternada - delineamentos teóricos e práticos - Artigo publicado no Publicada no Jus Navigandi, 2005). Disponível em http://jus. com.br/artigos/7335/guarda-compartilhada-x-guarda-alternada. Acesso em: 29 jul. 2013.

LEVY, Fernanda Rocha Lourenço. Guarda de filhos: os conflitos no exercício do poder familiar. São Paulo: Atlas, 2008.

LOTUFO, Maria Alice Zaratin. A guarda e o exercício do direito de visita. Revista do Advogado. São Paulo, v. 27, n. 91, maio, 2007.

PEREIRA, Caio Mário da Silva. Instituições de direito civil: direito de família, v. V, 2012, p. 18-19.

RIZZARDO, Arnaldo. Direito de família. Rio de Janeiro: Forense, 2006.

ROBLES, Tatiana. Guarda Compartilhada e Mediação. Disponível em: www.ibdfam.org. br/?artigos\&artigo=70, 2009 . Acesso em: 24 jul. 2013.

TEPEDINO, Gustavo. A disciplina da guarda e a autoridade parental na ordem civil constitucional. In: PEREIRA, Rodrigo da Cunha (Coord.) Anais do IV Congresso Brasileiro de Direito de Família. Belo Horizonte. Del Rey, 2004, p. 313. 
TRINDADE, Jorge. Síndrome de alienação parental (SAP). In: DIAS, Maria Berenice. Incesto e Alienação Parental: Realidades que a Justiça insiste em não ver. São Paulo: Editora Revista dos Tribunais, 2007, p. 110. 